\title{
Driving ban for diesel-powered vehicles in major cities: an appropriate penalty for exceeding the limit value for nitrogen dioxide?
}

\author{
Matthias Möhner ${ }^{1}$ (D)
}

Received: 17 January 2018 / Accepted: 20 February 2018 / Published online: 22 February 2018

(c) The Author(s) 2018. This article is an open access publication

To protect the general population from adverse health effects, Germany set a limit value of $40 \mu \mathrm{g} / \mathrm{m}^{3}$ for the annual mean exposure to nitrogen dioxide $\left(\mathrm{NO}_{2}\right)$ based on WHO's air-quality guidelines and in accordance with the European directives (DE 2010; EC 2008; WHO 2006).

According to the German Environment Agency, in 2017 this limit value was exceeded at $46 \%$ of the urban trafficrelated air monitoring stations (Minkos et al. 2018). The European Directive recommends severe sanctions for exceeding the limit value: "The penalties provided for must be effective, proportionate and dissuasive" (EC 2008). Since diesel-powered vehicles are regarded as the main trafficrelated source of nitrogen oxides, driving bans for innercity areas in many large German cities such as Hamburg, Munich, and Stuttgart are the subject of intense debate. In the passenger car sector alone, $80 \%$ of the currently around 15 million diesel-powered passenger cars registered are unlikely to meet the EURO 6 standard (Kraftfahrt-Bundesamt 2017) and would, therefore, be threatened by a local driving ban.

In contrast to Europe, the corresponding limit value for $\mathrm{NO}_{2}$ in the United States has been $100 \mu \mathrm{g} / \mathrm{m}^{3}$ since the 1970s. For the forthcoming periodic review of limit values, the US Environmental Protection Agency (EPA) recommends retaining the current value for $\mathrm{NO}_{2}$ (EPA 2016, 2017). Even the highest annual average value measured in Germany in 2016 [Stuttgart, Neckartor: $82 \mu \mathrm{g} / \mathrm{m}^{3}$ (Minkos et al. 2017)] was below the US-value, i.e. if the US value were also valid in Europe, a ban for diesel-powered vehicles would not be an issue in Germany at all. If the difference in limit values can have such serious consequences, it is indeed necessary to question why the WHO and EPA boards

Matthias Möhner

Moehner.Matthias@baua.bund.de

1 Division of Work and Health, Federal Institute for Occupational Safety and Health, Nöldnerstr, 40/42, 10317 Berlin, Germany arrived at different conclusions, even though the body of available studies is approximately equal. The difference in the two assessments is most likely due to differences in the critical examination of risk of bias in epidemiological studies. There are no epidemiological studies that can be confidently used quantitatively to estimate long-term $\mathrm{NO}_{2}$ exposure durations or concentrations likely to be associated with the induction of unacceptable health risks in children or adults. The most relevant publications in this context, which argue for adverse health effects of $\mathrm{NO}_{2}$, are based on the Harvard Six Cities Study. The investigators analyzed combined respiratory symptoms of children aged 7-11 years based solely on parental reports with incompletely assessed exposure to gas stove emissions (Neas et al. 1991). These results form the basis for WHO's first recommendation of $40 \mu \mathrm{g} / \mathrm{m}^{3}$ as a long-term limit value for $\mathrm{NO}_{2}$ (WHO 1997). Later, these study results gained further support by the application of measurement error correction methods to the study data (Li et al. 2006). In contrast, a large prospective study in infants exposed to a similar environment showed no health effects related to $\mathrm{NO}_{2}$ exposure (Samet et al. 1993). However, the WHO group argued that the likelihood of causation of adverse health effects by $\mathrm{NO}_{2}$ is strengthened because (a) epidemiological results are replicated across different studies with variable underlying conditions; (b) multiple health outcomes appear to be affected in a consistent and coherent manner; and (c) the results are supported by either toxicological or controlled studies on humans (WHO 2006). In the EPA report, the complex problems involved in risk assessment are discussed very decidedly: there is a need to consider (a) exposure factors potentially correlated with $\mathrm{NO}_{2}$ exposure in evaluating relationships with health effects, (b) factors contributing to error in estimating exposure to ambient $\mathrm{NO}_{2}$ and (c) confounding bias (EPA 2016).

$\mathrm{NO}_{2}$ is regarded as a marker for air pollution caused by motorized road traffic. The combustion processes also release particulate matter (PM) with aerodynamic diameter $<10 \mu \mathrm{m}\left(\mathrm{PM}_{10}\right)$ or the even smaller part $\left(\mathrm{PM}_{2.5}\right)$ as well as 
the gaseous pollutants sulfur dioxide $\left(\mathrm{SO}_{2}\right)$, nitrogen monoxide (NO), ozone, carbon monoxide (CO), and volatile organic compounds (VOCs). The correlation between these components at the monitoring points is typically greater than 0.80 . Moreover, road abrasion, brake wear and tire wear are non-exhaust traffic emissions that cause additional exposure to particulate matter containing silica, iron, zinc, copper, elemental carbon, barium and others. Toxicological and epidemiological research increasingly indicates that such non-exhaust pollutants could be responsible for some of the observed adverse effects on health (Gent et al. 2009; WHO 2013). It should be noted that for some health impairments, traffic noise must also be considered as a potential cause. In its conclusion the EPA, therefore, emphasizes that the extent to which $\mathrm{NO}_{2}$ may be serving primarily as a surrogate for the broader traffic-related pollutant mix remains unclear (EPA 2017).

The measured values for $\mathrm{NO}_{2}$ as well as for other trafficrelated pollutants are usually gathered via the permanently installed monitoring network, which primarily takes into account heavily exposed road sections. In terms of their spatial distribution, however, the pollutants differ considerably from one another. The exposure to $\mathrm{PM}_{10}$ is fairly homogeneous, i.e. a measured value at a central site is representative of a larger area. But $\mathrm{NO}_{2}$ spreads close to the ground locally. The variation of the exposure in inner-city areas depends not only on the distance from a major road, traffic characteristics, industrial point sources and housing or population density and some other land-use data available from geographic information systems (GIS), but also very much on the concrete development and design of the green spaces at micro level. For example, a study in Bavaria has shown that in the inner courtyard of a house, for which very high values were measured on the street side with above $80 \mu \mathrm{g} / \mathrm{m}^{3}$ $\mathrm{NO}_{2}$, the measurements were at the level of the urban background (Schädel et al. 2015). Thus, central site monitors and improved estimates derived from land-use regression models may not represent the magnitude of long-term average $\mathrm{NO}_{2}$ concentrations for study subjects in their residential environment. Consequently, the observed correlation between $\mathrm{NO}_{2}$ and other traffic-related pollutants at central cites may not represent the real correlation for study subjects.

In addition to the impact of other traffic-related pollutants, the socio-economic status (SES) of study subjects must also be taken into account when comparing different urban districts. Results of studies conducted in North America and Europe show a negative correlation between $\mathrm{NO}_{2}$ exposure and SES in terms of education, employment class or household income (Finkelstein et al. 2005; Naess et al. 2007). It has also been shown that SES is inversely correlated with morbidity and mortality of diseases such as cancer or cardiovascular diseases, mainly due to lifestyle factors (Galobardes et al. 2006; Power et al. 2005; Vohra et al. 2016). One such confounding factor to be taken into consideration is smoking. Unfortunately, most studies provide, if at all, very rough information on smoking (current smoker, ex-smoker, never smoker). Hence, residual confounding is an issue for many studies.

With regard to the risk-of-bias discussion carried out in the WHO report (WHO 2006), it should be noted that the effect direction of confounding variables does not differ between studies and that comparable methods of exposure assessment have been used, so that the bias directions are likely to be similar. Moreover, smoking and SES are known risk factors for most diseases for which correlation with $\mathrm{NO}_{2}$ exposure has been observed.

When discussing the health effects of $\mathrm{NO}_{2}$, it is also important to bear in mind the impact of carbon dioxide $\left(\mathrm{CO}_{2}\right)$ emissions on the environment. Diesel is burned more efficiently in the engines than gasoline, which is why the diesel engine emits less $\mathrm{CO}_{2}$ than a comparable gasoline engine. The increasingly efficient engines have led to a reduction of the specific emission (emission per passenger-kilometer) of $\mathrm{CO}_{2}$ since 1995 of 13 percent for passenger cars (UBA 2017). Other specific emissions were reduced even more significantly in this period, including $\mathrm{NO}_{2}$ at $60 \%$ and $\mathrm{PM}$ at $72 \%$. However, the trend towards ever larger and more powerful passenger cars unfortunately implicates that the continuous increase in the efficiency of combustion engines could not be translated into an overall reduction in fuel consumption. During the same period, the annual mean concentration in the atmosphere of global $\mathrm{CO}_{2}$ rose by more than $13 \%$ (NOAA 2017) contributing to climate change with observed and projected adverse impacts on health. If the concern is human health, the primary goal must, therefore, be to reduce global $\mathrm{CO}_{2}$ emissions noticeably. In terms of road traffic as one of the main sources of these emissions, this means that a turnaround towards lighter and, therefore, less motorized vehicles must be initiated. The combustion engines must be made more efficient and their emissions must be further reduced. A general speed limit on motorways could help to slow down the drive for ever more powerful engines in passenger cars. In addition, the attractiveness of public transport must also be significantly increased. However, the biggest challenge that needs to be addressed is the rapid development of truly climate-neutral mobility, including the longterm and environmentally compatible extraction of the raw materials required as well as efficient energy storage. More research is needed in this field. Research initiatives such as Sodium-Magnesium Hybrid Batteries (Walter et al. 2015) or synthetic, $\mathrm{CO}_{2}$-neutral fuel for combustion engines (Leitner et al. 2017; Pischinger 2016) are promising approaches. Like the diesel engine, e-mobility, which is based on lithium-ion batteries, will probably only prove to be a bridging technology. The most important raw materials, especially lithium and cobalt, are probably not available in sufficient quantities 
and the way in which they are extracted is partly subject to problematic conditions.

In view of these challenges to the sustainability of our mobility and taking into account the described weaknesses of epidemiological evidence for an adverse health effect of $\mathrm{NO}_{2}$ emissions, a ban on the use of diesel-powered vehicles seems disproportionate.

\section{Compliance with ethical standards}

Conflict of interest The author declares that he has no potential conflicts of interest. In particular, he points out that he neither holds any shares in automobile manufacturers nor does he own a diesel car himself.

Open Access This article is distributed under the terms of the Creative Commons Attribution 4.0 International License (http://creativeco mmons.org/licenses/by/4.0/), which permits unrestricted use, distribution, and reproduction in any medium, provided you give appropriate credit to the original author(s) and the source, provide a link to the Creative Commons license, and indicate if changes were made.

\section{References}

DE (2010) 39. Verordnung zur Durchführung des Bundes-Immissionsschutzgesetzes (Verordnungüber Luftqualitätsstandards und Emissionshöchstmengen-39. BImSchV) BGB1 I $2010 \mathrm{Nr} 40$. 05.08.2010 edn, Bonn, pp 1065-1104. https://www.gesetze-iminternet.de/bimschv_39/BJNR106510010.html

EC (2008) Directive 2008/50/EC of the European Parliament and of the Council of 21 May 2008 on ambient air quality and cleaner air for Europe. Off J Eur Union L 152. https://www.ecolex.org/details/ legislation/directive-200850ec-of-the-european-parliament-andof-the-council-on-ambient-air-quality-and-cleaner-air-for-europ e-lex-faoc080016/

EPA (2016) Integrated Science Assessment for Oxides of NitrogenHealth Criteria. U.S. EPA, Research Triangle Park, NC, p 1148. https://www.epa.gov/isa/integrated-science-assessment-isa-nitro gen-dioxide-health-criteria

EPA (2017) Policy assessment for the review of the primary national ambient air quality standards for oxides of nitrogen. U.S. EPA, Research Triangle Park, NC, p 436. https://www.epa.gov/naaqs/ policy-assessment-review-primary-national-ambient-air-qualitystandards-oxides-nitrogen

Finkelstein MM, Jerrett M, Sears MR (2005) Environmental inequality and circulatory disease mortality gradients. J Epidemiol Community Health 59(6):481-487. https://doi.org/10.1136/ jech.2004.026203

Galobardes B, Smith GD, Lynch JW (2006) Systematic review of the influence of childhood socioeconomic circumstances on risk for cardiovascular disease in adulthood. Ann Epidemiol 16(2):91104. https://doi.org/10.1016/j.annepidem.2005.06.053

Gent JF, Koutrakis P, Belanger K, Triche E, Holford TR, Bracken MB, Leaderer BP (2009) Symptoms and medication use in children with asthma and traffic-related sources of fine particle pollution. Environ Health Perspect 117(7):1168-1174. https://doi. org/10.1289/ehp.0800335

Kraftfahrt-Bundesamt (2017) Fahrzeugzulassungen (FZ) Bestand an Kraftfahrzeugen nach Umwelt-Merkmalen. vol FZ 13, Flensburg. https://www.kba.de/SharedDocs/Publikationen/DE/Statistik/Fahrz euge/FZ/2017/fz13_2017_pdf.html
Leitner W, Klankermayer J, Pischinger S, Pitsch H, Kohse-Hoinghaus K (2017) Advanced biofuels and beyond: chemistry solutions for propulsion and production. Angew Chem Int Edit 56(20):54125452. https://doi.org/10.1002/anie.201607257

Li R, Weller E, Dockery DW, Neas LM, Spiegelman D (2006) Association of indoor nitrogen dioxide with respiratory symptoms in children: application of measurement error correction techniques to utilize data from multiple surrogates. J Expo Sci Environ Epidemiol 16(4):342-350. https://doi.org/10.1038/sj.jes.7500468

Minkos A, Dauert U, Feigenspan S, Kessinger S (2017) Jährliche Auswertung NO2-2016. Umweltbundesamt. https://www.umweltbund esamt.de/publikationen/luftqualitaet-2016

Minkos A, Dauert U, Feigenspan S, Kessinger S, Nordmann S, Himpel T (2018) Luftqualität 2017. Umweltbundesamt, p 28. https://www. umweltbundesamt.de/publikationen/luftqualitaet-2017

Naess O, Piro FN, Nafstad P, Smith GD, Leyland AH (2007) Air pollution, social deprivation, and mortality: a multilevel cohort study. Epidemiology 18(6):686-694. https://doi.org/10.1097/EDE.0b013 e $3181567 d 14$

Neas LM, Dockery DW, Ware JH, Spengler JD, Speizer FE, Ferris BG $\mathrm{Jr}$ (1991) Association of indoor nitrogen dioxide with respiratory symptoms and pulmonary function in children. Am J Epidemiol 134(2):204-219

NOAA (2017) Trends in atmospheric carbon dioxide. U.S. Department of Commerce, NOAA Earth System Research Laboratory. https:// www.esrl.noaa.gov/gmd/ccgg/trends/global.html\#global_growth

Pischinger S (2016) Current and future challenges for automotive catalysis: engine technology trends and their impact. Top Catal 59(10-12):834-844. https://doi.org/10.1007/s11244-016-0557-3

Power C, Graham H, Due P, Hallqvist J, Joung I, Kuh D, Lynch J (2005) The contribution of childhood and adult socioeconomic position to adult obesity and smoking behaviour: an international comparison. Int J Epidemiol 34(2):335-344. https://doi. org/10.1093/ije/dyh394

Samet JM, Lambert WE, Skipper BJ, Cushing AH, Hunt WC, Young SA, McLaren LC, Schwab M, Spengler JD (1993) Nitrogen dioxide and respiratory illnesses in infants. Am Rev Respir Dis 148(5):1258-1265. https://doi.org/10.1164/ajrccm/148.5.1258

Schädel S, Schmid S, Wellhöfer A, Weigand S, Ott H, Pitz M (2015) Untersuchung der räumlichen Verteilung der NOx-Belastung im Umfeld von vorhandenen, hochbelasteten Luftmessstationen. Bayerisches Landesamt für Umwelt, Augsburg, p 291. https://www.bestellen.bayern.de/application/eshop_app00 0008?SID=1576855271\&ARTSUCHExMATCHCODE=Unter suchung+der+r\%E4umlichen+Verteilung+der+NOx-Belas tung $+\mathrm{im}+$ Umfeld + von $+\& \mathrm{x}=0 \& \mathrm{y}=0 \&$ ARTSUCHExMATCHC $\mathrm{ODE}=\&$ ACTIONxSETVAL $\% 28$ suchergebnisse.htm $\% 2$ CUSE RxTITLE\%3ASuchergebnisse $\% 29=x$

UBA (2017) Emissionen des Verkehrs. https://www.umweltbundesamt .de/daten/verkehr/emissionen-des-verkehrs\#textpart-1

Vohra J, Marmot MG, Bauld L, Hiatt RA (2016) Socioeconomic position in childhood and cancer in adulthood: a rapid-review. J Epidemiol Community Health 70(6):629-634. https://doi.org/10.1136/ jech-2015-206274

Walter M, Kravchyk KV, Ibáñez M, Kovalenko MV (2015) Efficient and inexpensive sodium-magnesium hybrid battery. Chem Mater 27(21):7452-7458. https://doi.org/10.1021/acs.chemmater.5b035 31

WHO (1997) Nitrogen oxides (2nd edn) —environmental health criteria 188 WHO, Geneva. http://www.inchem.org/documents/ehc/ehc/ ehc188.htm

WHO (2006) WHO Air quality guidelines for particulate matter, ozone, nitrogen dioxide and sulfur dioxide - Global update 2005. http:// www.euro.who.int/en/health-topics/environment-and-health/airquality/publications/pre2009/air-quality-guidelines.-global-updat 
e-2005.-particulate-matter,-ozone,-nitrogen-dioxide-and-sulfu r-dioxide

WHO (2013) Review of evidence on health aspects of air pollution - REVIHAAP Project. p 309. http://www.euro.who.int/en/healt h-topics/environment-and-health/air-quality/publications/2013/ review-of-evidence-on-health-aspects-of-air-pollution-revihaapproject-final-technical-report 